\title{
Koelvest behoort inmiddels tot de standaard uitrusting
}

Nannet van der Geest en Thijs Eijsvogels

In het interview COVID-verpleegkundige komt beter de dienst door met koelvest werden de eerste resultaten gedeeld van onderzoek naar het effect van dragen van koelvesten in de fysiek zware COVID-19--zorg (TBV, januari 2021).

Inmiddels zijn de resultaten gepubliceerd in het vakblad Temperature en behoort het koelvest bij de standaarduitrusting van de verpleegkundige op de COVID-19-afdeling in het Radboudumc. Ook is het koelvest hier reeds geïmplementeerd in de omkleedprocedure behorend bij de zorg voor patiënten met Viraal Hemorrhagische Koorts (Ebola e.a.)

Buiten het Radboudumc hebben ook andere ziekenhuizen veel interesse in het gebruik van de koelvesten, evenals de GGD en verpleegtehuizen.
Daarnaast is het denkbaar dat koelvesten ingezet worden bij andere beroepsgroepen, bijvoorbeeld bij brandweer, politie of werknemers in de industrie waar hittestress aan de orde is. Het gebruik van het koelvest is weergegeven in onderstaand schema. Het vest geeft ongeveer 3 uur koeling wat precies overeenkomt met een shift in de COVID-19-zorg (dan moet ook het masker verwisseld worden). Na 2-2,5 uur koelen in de koelkast is het vest weer te gebruiken voor een nieuwe shift van 3 uur.

\section{Referenties}

De Korte J, Bongers C, Catoire M, Kingma B, Eijsvogels T. Cooling vests alleviate perceptual heat strain perceived by COVID-19 nurses. Temperature, December 2020 https://doi.org/10.1080/ 23328940.2020.1868386

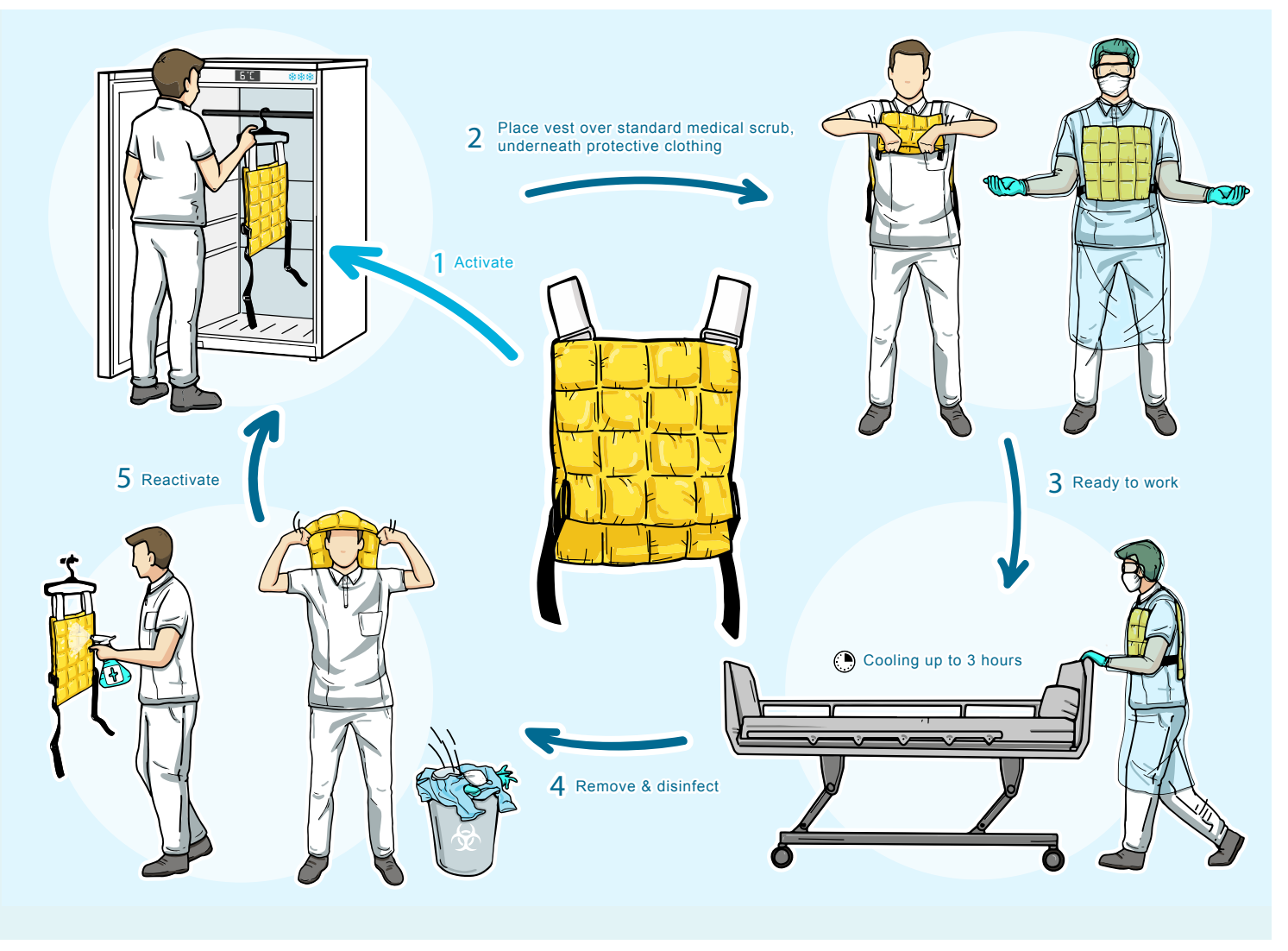

